\title{
Buyer-Supplier Relationship and Service Performance: an Operations Perspective Analysis
}

\author{
Ely Laureano Paiva \\ Unisinos \\ elpaiva@unisinos.br \\ Patricia Phonlor \\ Unisinos \\ phonlor@gmail.com \\ Lívia Castro D’avila \\ Unisinos \\ livia@vetorial.net
}

\begin{abstract}
SUMMARY: This article analyzes the influence of the buyer-supplier relationship continuity on service performance. We used a survey with a sample of 53 companies that are users of international maritime transport belonging to two industries: Machinery and Food. The results related to Service Performance are similar to those found in past studies in industrial supply chains. The traditional performance criteria like delivery, dependability and cost clearly are influenced by the aspects related to the management of the relationship. This includes information exchange, trust and interaction between the parts.
\end{abstract}

KEYWORDS: service operations, buyer-supplier relationship, performance.

\section{INTRODUCTION}

The influence of the relationship strategies between buyer-supplier on the performance depend on the benefits perceived by both parts. Among the factors that may influence this relationship, we may highlight two main groups. Firstly, we may mention the service's operational standards. They are related to the supplier's performance criteria (quality, flexibility, dependability, costs). Complementarily, these criteria influence the relationship continuity through intrinsic characteristics, such as communication, cOoperation and problem solving (PAYNE, BALLANTYNE, 2001). This second group is usually neglected in the research on this topic, even though it influences benefits and costs of the relationship (WINNER et al., 2005). In this way, we may address the following research question: the type of relationship between buyer and supplier is a relevant aspect for service performance? Therefore, the objective of this article is to analyze the influence of criteria related to the relationship supplier-buyer in the performance of services from an operations management approach. The research was carried out using exports companies in international maritime transporters in two industries: Machinery and Food. The choice for this type of service was related to the nature of the relationship continuity between the parts. This service is characterized by a standardized offer and supplier changes may arise frequently. Moreover, the two industries analyzed are leader in exports in the state of Rio Grande do Sul.

The article is structured as follows: initially we present the literature on buyer-supplier relationship, 
especially in service industry. After we present the methodological procedures as well the results found. Finally, the study's conclusions are discussed.

\section{LITERATURE REVIEW}

\section{Buyer-supplier relationship in Services}

In service industry, Berry and Parasuraman (1991) stated that the relationship between buyer-supplier requires trust, considering that the customer typically purchases a service before experiencing it. After the first experience with the service, trust and loyalty can be developed through the relationship between the parts. In exports, the exchange of confidential information (or strategic information) is relatively common. In this way, the necessary trust may lead to a higher level of commitment between buyer and supplier.

Communication effectiveness, cooperation and transparency constitute key factors for trust development.

According to Mohr and Nevin (1990), there are four categories of communication: content, way, feedback and frequency. These categories will shape the communication intensity and the integration between supplier-buyer. Moreover, the communication plays important role in the integration with distribution channel, because it allows the suppliers to improve the performance according to the customer's needs. In a highly integrated buyer-supplier relationship, the supply chain because an important and valuable source of information. The type of information received, according to Gulati and Gargiulo (1999), will be more "intense" compared to that one ones received directly from the market. In a vertically integrated chain, information access and supply flow through the formal and informal hierarchic structure. Relationship between the parts would create a wide channel of rich information dissemination. Thus, information value is related again on its content and credibility more than the infrastructure that makes possible the information sharing.

\section{Relationship in the Supply Chain}

According to the main authors in supply chain management (SCM), a cooperation-based relationship between supply chain partners brings some advantages. Supply chain management includes actions re- lated to process integration, collaboration, information sharing, and usually it leads to the high levels of client's satisfaction. Furthermore, SCM may improve performance in costs, quality, delivery and flexibility (BECHTEL; JAYARAM; 1997; MENTZER, 2001). According to Prahinski and Benton (2004), supplier development programs lead to improvements in operational performance when the supplier is committed with the buyer. Such improvements would be on to the supplier's perception regarding the commitment, loyalty and relationship longevity. In this case, buyers may influence the supplier's commitment and the communication intensity and, consequently, improve the relationship. Relationship development would include cooperation increase, shared problem solving, commitment actions, loyalty and long term relationship orientation. Morgan and Hunt (1994) stated that trust and commitment are central aspects for the supply relationship success. As these authors argue, some aspects are important to encourage the relationship continuity. Among them, we may mention: long term cooperation between the partners; waited benefits related to the link with the partners instead of short term alternatives; and possible high risk actions for believing that the partners will not act opportunistically. Therefore, when commitment and trust are present, they promote efficiency, productivity and effectiveness. Shortly, commitment and trust lead directly to cooperation behaviors that in turn, would allow relationship continuity. Similarly, Anderson and Weitz (1991) have shown that the commitment of each supply chain link is based on its commitment perception regarding the other members. In this way, buyer's commitment influences positively supplier's commitment.

Trust is another central aspect for the relationship continuity. This aspect is identified when a partner has certainty of trustworthiness and integrity of its partners (MORGAN; HUNT; 1994). Integrity is associated with reliable quality, ability, honesty, justice, responsibility, attendance and benevolence (DWYER; LAGRACE; 1986; ROTTER; 1971 apud MORGAN; HUNT; 1994). Companies hesitate to trust in a supplier without first testing it. Afterwards, it is possible to build an effective relationship that seeks to achieve performance objectives (PRAHINSKI; BENTON; 2004). Prahinski and Benton (2001) analyzed the relationship between buyer-supplier according to three attributes: commitment, cooperation and operational linking. These attributes indicate some important characteristics of a relationship, including behavior and operational aspects. Kumar (1995) 
also identified three components for commitment: investments in the business partner, affective commitment and long term relationship expectation. In this way, we claim that operational linking is also relevant because it leads to information exchange and operational performance evaluation. This evaluation is based on the operational measures like cost, quality and delivery time, among others.

\section{Performance and Relationship}

Business-oriented measures of performance traditionally are related to company's internal activities or competitive environment. Presently, competition became wider, taking place between supply chains instead of among single companies. Company's performance may be jeopardized if its partners do not achieve an expected performance. Thus, performance depends on the effectiveness of businessoriented relationships with a clear interdependence between partners (WINNER et al., 2005). In this case, interdependence between companies occurs when the involved parts in the relationship are integrated among themselves. Therefore, we may state that the company's abilities are influenced not only by internal activities, but also by partners' activities, including suppliers, other partners and clients. In the service analyzed, exporters and suppliers of international maritime transport has the delivery performance overlapped between transporter and exporter. This occurs because the direct responsible for the delivery is the transporter. However, the final client usually evaluates delivery performance as an exporter's attribute.

\section{Competitive criteria in Services}

The competitive criteria are defined as a consistent set of priorities that a company chooses to compete in its market (PAIVA et. al, 2004). Usual competitive criteria in the literature are: cost, quality, dependability and flexibility. Wheelwright (1984) identified this group as well as other authors in operations management literature (NEW, 1992; SLACK et al., 1999; WORM; THOMPSON; 1999). Dependability criterion is related to the confidence that the product will work in accordance to the specifications or, in the case of services, that the deliveries will be at the right time and the problem solutions will occur in a short time (WHEELWRIGHT, 1984). There are slight variations of this competitive criteria group (HAYES; PISANO; 1996, PAIVA et al., 2004). Some authors instead of the criterion dependability iden- tifies time delivery as the four competitive criterion. These competitive criteria usually are more suited to manufacturing. Some singularities should be considered in service operations.

Servqual (PARASURAMAN ET AL., 1988) was one of the first scale in identifying performance criteria in services. The authors identified five criteria: tangibles, reliability, responsiveness, assurance and empathy. Fitzsimmons and Fitzsimmons (2000) complementarily proposed other group of performance criteria in services. The performance criteria cited by them are: availability; convenience; dependability; customization; price; quality (a function of customer's previous expectations and perceptions); reputation (when the choice for a service may be influenced by word-to-mouth); security and speed.

Specifically in the international maritime transport, Brooks (1993) identified the main criteria considered by exporters for service transport supplier choice. Among others, three were more relevant: scale frequency (in the departure port), freight cost, and transportation time. Complementarily, other criteria were identified by Canadian exporters, including: service cost; direct transportation (without scales); collecting as expected; delivery as expected; next ship departure to the requested destination; cooperation between transporter and exporter; transporter flexibility to solve problems in the ports; traceability; quick response to requests/claims; long term commitment; sales service; experiences related to loss or damages in the loads. Considering the competitive criteria in literature, the existence of trade-offs between these criteria is another relevant aspect. In this case, companies would seek to achieve a high performance in a narrow group of criteria and seek why there are existing incompatibilities between two or more criteria.

The competitive criteria identified by Fitzsimmons and Fitzsimmons (2000) and Parasumaram et al. (1988) with the inclusion of flexibility were the base for the scales in this study. The criteria proposed by Brooks (1990) completed the questionnaire.

\section{METHOD}

We used a survey for the data collection. The first step to define the questions was a set of in depth interviews with executives from exports companies belonging to the selected industries (Machinery and Food). The questions are related to services competitive criteria and relationship. A Likert's scale with 
5 points from Completely Disagree to Completely Agree was chosen.

Three specialists from the international maritime transport companies (managers of international maritime transport companies) evaluated the first version of the questionnaire regarding to face and content validity (HAIR et al., 2005; MALHOTRA, 2004). Based on their suggestions, we adjusted the questions' content.

We applied a pilot test to four exporters companies belonging to the two industries in order to identify possible problems related to clarity and relevance. After the overall analysis and new round of adjustments, the final version of the questionnaire presented 31 questions. The questions are listed in the Appendix 1.

Exports companies located in the state of Rio Grande do Sul from Machinery and Food industries composed the population. We chose these two industries because they are leaders in exports amount in this state. Due to the number of companies, the sample included only companies with more than US\$ 1 million exports in the year of 2005. We used the data base from the Brazilian Ministry of Development and International Trade (Ministério do Desenvolvimento Indústria e Comércio Exterior - MDIC).

We contacted 213 companies by telephone. We excluded 31 companies (23 because they used only one transport modality, in which the freight is paid abroad, and 9 for having ended their activities or no contact identification). Considering the sample of 181 companies, the final number of respondents was $53(29 \%)$.

It is important to mention that a respondent was identified as an outlier after running the initial statistical analyses. Thus, we excluded this respondent from the final analysis. We identified a significant difference compared to the other respondents using the graphical analysis of the data normality (HAIR et al., 2005). With the exclusion, Cronbach's alpha coefficients did not change significantly. Thus, $52 \mathrm{com}-$ panies composed the final sample in the analysis.

\section{Sample characteristics}

Based on the descriptive statistics, $60 \%$ of the respondents belong to companies with more than 100 employees.

The final sample was composed by 33 (62\%) compa- nies from Machinery industry, and 20 (38\%) companies from Food industry.

The respondent's profile was exports operators $(40 \%)$, supervisors $(34 \%)$, coordinators $(15 \%)$, general managers $(8 \%)$ and directors (4\%). The majority of them $(60 \%)$ have more than 5 years of experience in exports. Analyzing the number of international maritime transport suppliers, the results showed that the companies prefer to work with a small number of suppliers. This orientation probably help them in concentrating their improvement efforts (PRAHINSKI; BENTON; 2004; SHIN et al., 2000). The data indicated that $75 \%$ of the respondents use up to 5 (five) companies for international maritime transport, what may considered as a reduced number of suppliers in this type of activity.

\section{RESULTS}

\section{Exploratory factor analysis}

Kaiser-Meyer-Olkin (KMO) test of adequacy and Bartlett's sphericity test were applied to evaluate the use of exploratory factor analysis (EFA). KMO test presented a value equal to 0.55 , indicating the data adequacy to factor analysis. Complementarily, the Bartlett's test presented a significance of 0.00 , what also qualifies the data for a factor analysis application (MALHOTRA, 2004). Considering four factors in the EFA, the explained variance was equal to $75.32 \%$, what exceeds the recommended minimum value $(60 \%)$. We used a principal components method with Varimax rotation. The final matrix indicated four factors, after the removal of items with low factorial loadings. We evaluated scales' reliability through the Cronbach's alpha coefficient (Table 1). All the results achieved satisfactory levels with exception of Suppliers Management (0.61). This value of Cronbach's alpha indicates some caution even though Malhotra (2004) considers it as acceptable. Thus, the scales may be described as:

- Commitment includes the questions related to the exporter's commitment with the international maritime transport supplier, such as: comparison results with other suppliers are used as bargain with current suppliers; existing relationship influences the supplier choice process; comparison with other suppliers is usual; there is effective commitment with suppliers;

- Relationship Continuity includes questions relative to: supplier is cooperative in problems solving; 
longevity expectation is shown in some way (in case that it does not have expectation does not mark no option); there is an expectation of long term relationship with these suppliers;

- Communication is the scale that characterizes the existing communication between supplier and exporter. It evaluates whether the objectives concerning communication are achieved and whether the communication flows clearly;

- Suppliers Management evaluates the investment in suppliers (for qualification); uses formal methods for supplier selection; priorizes long-term relationship.

Table 1 - Rotated factorial matrix for relationship variables.

\begin{tabular}{|c|c|c|c|c|}
\hline & Factor 1 & Factor 2 & Factor 3 & Factor 4 \\
\hline $\begin{array}{l}\text { Factor } \\
\text { Name }\end{array}$ & Commitment & $\begin{array}{l}\text { Relationship } \\
\text { Continuity }\end{array}$ & Communication & $\begin{array}{c}\text { Supply } \\
\text { Management }\end{array}$ \\
\hline $\begin{array}{l}\text { The results of this comparison are } \\
\text { used as bargain with current suppliers }\end{array}$ & 0.82 & & & \\
\hline $\begin{array}{l}\text { Existing relationship influences the } \\
\text { supplier choice process }\end{array}$ & 0.76 & & & \\
\hline $\begin{array}{l}\text { We compare other suppliers to our } \\
\text { current suppliers }\end{array}$ & 0.75 & & & \\
\hline $\begin{array}{l}\text { There is affective commitment with } \\
\text { suppliers }\end{array}$ & 0.70 & & & \\
\hline $\begin{array}{l}\text { The supplier is cooperative in } \\
\text { problems solving }\end{array}$ & & 0.92 & & \\
\hline $\begin{array}{l}\text { Longevity expectation is shown in } \\
\text { some way (in case it does not have } \\
\text { expectation do not mark no option) }\end{array}$ & & 0.84 & & \\
\hline $\begin{array}{l}\text { There is a expectation of long term } \\
\text { relationship with these suppliers }\end{array}$ & & 0.67 & & \\
\hline $\begin{array}{l}\text { Objectives with the communication } \\
\text { are achieved }\end{array}$ & & & 0.92 & \\
\hline Communication flows clearly & & & 0.77 & \\
\hline $\begin{array}{l}\text { We invest in suppliers (for } \\
\text { qualification) }\end{array}$ & & & & 0.85 \\
\hline $\begin{array}{l}\text { We use formal election of suppliers } \\
\text { methods, with clearly defined criteria }\end{array}$ & & & & 0.76 \\
\hline We prioritize long-term relationships & & & & 0.61 \\
\hline$\%$ Variance & 3.25 & 2.58 & 1.78 & 1.42 \\
\hline$\%$ Cumulative & 27.12 & 21.52 & 14.83 & 11.86 \\
\hline Total & 27.12 & 48.64 & 63.46 & 75.32 \\
\hline Cronbach's Alpha & 0.72 & 0.76 & 0.82 & 0.61 \\
\hline
\end{tabular}


We investigated also the questions related to service's competitive criteria in international maritime transport. We analyzed the KMO test for sample adequacy and the Bartlett's sphericity test. Both showed satisfactory values. KMO value was equal to 0.85 and the Bartlett's test presented a significance of 0.00 , indicating a data adequacy for factor analysis application. Three factors were identified with $75.78 \%$ of the explained variance. We ran the analysis again with Varimax rotation method. Questions 2, 3, 4, 12 and 17 were excluded from the final factor analysis for presenting high loadings in more than one factor. After their exclusion, we applied the factor analysis again.

Table 2 shows the scales and reliability coefficients (Cronbach's alpha). The Cronbach's alpha ranged from 0.80 to 0.91 , indicating a satisfactory level of reliability. The scales may be described as:
- Service Performance presents relation with the operational characteristics of the international maritime transport supplier and it influences exporter's logistic performance. The questions are related to: capability related to expected time delivery; space and equipment availability; agile response to requests; capability related to service adaptation to my needs; service price; skilled and capable team.

- Dependability considers the questions related to right shipment documentation; quick availability of shipment documentation; correct payment document.

- Perceived Security includes company's market reputation (image); easy contact with supplier; traceability capability.

Table 2 - Rotated factorial matrix for variables related to service competitive criteria.

\begin{tabular}{|c|c|c|c|}
\hline & Factor 1 & Factor 2 & Factor 3 \\
\hline & Service Performance & Dependability & Perceived Security \\
\hline Capability related to expected time delivery & 0.77 & & \\
\hline Availability of space and equipment & 0.74 & & \\
\hline Agile requests response & 0.71 & & \\
\hline Capability related to service adaption the to my needs & 0.71 & & \\
\hline Service price & 0.69 & & \\
\hline Skilled and capable team & 0.62 & & \\
\hline Right shipment documentation & & 0.87 & \\
\hline Quick availability of shipment documentation & & 0.81 & \\
\hline Correct payment document & & 0.81 & \\
\hline Company's market reputation (image) & & & 0.78 \\
\hline Easy contact with supplier & & & 0.77 \\
\hline Traceability capability & & & 0.73 \\
\hline \% Variance Explained & 6.98 & 1.08 & 1.04 \\
\hline$\%$ Cumulative & 58.16 & 8.98 & 8.65 \\
\hline Total & 58.16 & 67.13 & 75.78 \\
\hline Cronbach's Alpha & 0.9 & 0.91 & 0.8 \\
\hline
\end{tabular}




\section{Regression Analysis}

We used a multiple regression analysis to analyze the influence of services competitive criteria and the relationship continuity criteria on service performance in international maritime transport. We considered the Service Performance as dependent variable and Commitment, Relationship Continuity, Communication, Supplier Management, Dependability and Perceived Security, as independent or predictors variables. Service Performance characterizes the operational performance of the international maritime transport suppliers. The results found were statistically significant with $\mathrm{R}^{2}$ equal to 0.745 , what it is a high value for management studies (HAIR et al., 2005).

The $\mathrm{F}$ test for model significance was equal to 0.00 , which indicates a statistically significant relation between the independent variables and the dependent variable (Table 3 ).

Table 3 - Testing for significance of model

\begin{tabular}{l|l|l|l|l|l}
\hline & $\begin{array}{l}\text { Square } \\
\text { Sum }\end{array}$ & DF & $\begin{array}{l}\text { Mean } \\
\text { squares }\end{array}$ & F & Sig. \\
\hline Regression & 22.648 & 6 & 3.775 & 21.921 & $.000(\mathrm{a})$ \\
Residual & 7.749 & 45 & .172 & & \\
Total & 30.397 & 51 & & & \\
\hline
\end{tabular}

We also analyzed the multicollinearity of the scales. Hair et al. (2005) state that VIF values should be lower than 5, which indicate that there is low correlation between the independent variables. The table shows that the independent variables are statistically independent, not characterizing multicollinearity.

Table 4 - Regression weights and analysis of colinearity

\begin{tabular}{|c|c|c|c|c|c|c|c|}
\hline & \multicolumn{2}{|c|}{$\begin{array}{l}\text { Non standardized } \\
\text { Coefficients }\end{array}$} & \multirow{2}{*}{$\begin{array}{c}\text { Standardized } \\
\text { coefficients }\end{array}$} & \multirow[t]{2}{*}{$\mathrm{t}$} & \multirow[t]{2}{*}{ Sig. } & \multicolumn{2}{|c|}{$\begin{array}{l}\text { Statistics from } \\
\text { colinearity }\end{array}$} \\
\hline & B & $\begin{array}{l}\text { Standard } \\
\text { error }\end{array}$ & & & & Tolerance & VIF \\
\hline (Constant) & .438 & .479 & & .915 & .365 & & \\
\hline Commitment & .005 & .081 & .005 & .057 & .955 & .881 & 1.135 \\
\hline Relationship Continuity & -.201 & .085 & -.198 & -2.369 & .022 & .809 & 1.237 \\
\hline Communication & .478 & .090 & .437 & 5.298 & .000 & .834 & 1.199 \\
\hline Suppliers Management & .039 & .082 & .045 & .481 & .633 & .662 & 1.510 \\
\hline Dependability & .214 & .093 & .253 & 2.289 & .027 & .463 & 2.161 \\
\hline Perceived Security & .409 & .097 & .429 & 4.202 & .000 & .543 & 1.840 \\
\hline
\end{tabular}

Dependent variable: SERVICE PERFORMANCE.

Moreover, we also analyzed the normality of residues, considering that in a multiple regression there is an estimate error of explained variance related to the residues. Thus, the analysis of the residues may identify problems caused by data that are not fitted to the multiple regression analysis assumptions.

The tested hypothesis is that the residues are normal. This hypothesis was accepted since the data indicated a non significant result $(\mathrm{sig}=0.200)$.

Finally, a homoscedasticity situation occurs in the regression analysis when the variance of the dependent variable is equal for all the data. We used the Breusch-Pagan's test in order to analyze to the homoscedasticity. The existence of this occurs when the data present normality of residues. Thus, the test identifies if the data present equal variances. The result found was not significant (0.970), what it indicates that the data presents homoscedasticity, as expected (HAIR et al, 2005). 


\section{Result Analyses}

Based on the multiple regression analysis, we identified that Communication and Perceived Security are two aspects that present high influence on Service Performance in the international maritime transport. According to Bechtel and Jayaram (1997), communication represents the base for supply chain management, with a relevant role for the continuity of a buyer-supplier relationship. This finding strengthens other studies that already have identified the role of Communication as an important aspect in the buyer-supplier relationship (TUTEN; URBAN; 2001; BECHTEL; JAYARAM; 1997; GAMMELGAARD; LARSON; 2001; MENTZER et al., 2001). Moreover, Communication also may influence the buyer's satisfaction (MOHR; SPEKMAN; 1994).

Perceived Security is another aspect with statistically significant influence on Service Performance. This scale is related to easy access to supplier, supplier's reputation and traceablity, aspects also identified by Brooks (1993). Beyond this, Dependability also presented a positive influence on Service Performance.

We claim that in this type of services, information related to the load location have a high importance for the exporter. The importance of aspects such as traceability and easy contact shows that, even with the wide dissemination of information and communication technologies, the traditional interaction through face-to-face or other direct contact between buyer-supplier still remain impostant. Moreover, supplier reputation in this activity is highlighted because usually there are high monetary amount involved in the transactions. The information flow that embedded in the buyer-supplier relation presents also relevant influence on service performance.

Shortly, we may state that the majority of statistical significant results indicate a clear relation to interaction between buyer-supplier.

Surprisingly Relationship Continuity showed a negative weight in the regression analysis. This aspect contradicts the common sense that a long-term relationship would be related to a better performance. A possible explanation for this result is that long-term relationships could lead to an adaptation between the parts and, therefore, creating a possible complacence to a low performance standards. Swink et al. (2007) also found similar results in manufacturing companies. Closely, anecdotal references indicate that Nissan faced similar situation with its suppli- ers. Carlos Ghosn's, Nissan's CEO at that time, developed a severe supplier evaluation during the company's recovery period (MAGEE, 2003).

\section{CONCLUSIONS}

This study aimed to identify the influence of the supplier-buyer relationship in the service performance from a buyer perspective. The results suggested that Service Performance is influenced by some basic aspects related to buyer-supplier interaction such as Communication, Perceived Security, and Dependability. These aspects are similar to those also identified by Mentzer et al. (2003) for supply chain management (SCM) implementation. These authors mention mutual information exchange and trust between the supply chain partners as essential for SCM success. Therefore, buyer-supplier interaction plays a relevant role regarding the relationship continuity and also influences positively service performance.

This result indicates the need to improve the interaction and communication processes between buyer and supplier. Thus, investments in employee qualification and advances in the use of the Information Technologies are recommendable actions for the service analyzed.

Perceived Security and Dependability also are factors that presented relation to interaction. The results showed that they influence positively the performance in international maritime transportation. Similarly, there are some important managerial implications, like the need for investments related to traceability based on Information Technologies.

Surprisingly, Relationship Continuity presented a negative correlation with Service Performance. This finding may be related to lower pressure levels in performance when the relationship between the parts exists for a long time probably without a formal evaluation process. A new supplier probably will be rigorously evaluated and existing errors showed without complacence. Further research deserve to be developed in this topic, because past studies have identified similar results.

In general, we may state that the overall results related to Service Performance in this study are close to the results found in the traditional manufacturing supply chains. The usual performance criteria such as delivery, dependability and cost are clearly influenced by aspects related to the relationship management. This includes information exchange, 
trust and, in general, interaction between the parts. Thus, there is a need for a new managerial mindset in service industry, not only related to the competitive approach (based in the bargaining power) but with a new relational vision present in studies like Dyer and Nobeoka (2000).

New studies may advance the results found in this research. Moreover, a broader analysis is recommendable seeking for other industries, other links in the supply chain or other aspects that may influence service performance. Finally, it is worth to highlight that the results should be considered with caution considering the sample size and the focus only on two industries.

\section{REFERENCES}

ANDERSON,E.; WEITZ, B. (1992). The Use of Pledges to Build and Sustain Commitment in Distribution Channels. Journal of Marketing Research, Vol. 29, No. 1, p. 18-34,

BECHTEL, C. JAYARAM, J. (1997). Supply chain management: a strategic perspective. The international Journal of Logistics Management. Vol. N. 8, pp. 15-34,

BERRY, L.L.; PARASURAMAN, A. (1991).Marketing Services: Competing Through Quality, Free Press, New York.

BROOKS, M. (1993). International Competitiveness - Assessing and Exploring Competitive Advantage by Ocean Container Carriers. Logistics and Transportation Review, Vol. 29, No. 3 , p. 275.

CHRISTOPHER, M.; PAYNE, A.; BALLANTYNE, D. (1991). Relationship marketing: Bringing quality, customer service and marketing together. Oxford: Butterworth-Heinemann..

DWYER, F. R.; LAGRACE, R. (1986). On the Nature and Role of Buyer-Seller Trust. AMA Summer Educators Conference Proceedings, Ed. T. Shimp et al. Chicago: American Marketing Association..

DYER, J.; NOBEOKA, K. (2000). Creating and managing a highperformance knowledge-sharing network: The Toyota case. Strategic Management Journal, Vol. 21, No. 3, p. 345-367..

FITZSIMMONS, J.; FITZSIMMONS, M. J. (2000). Administração de Serviços. 4⿳亠丷a edição. Porto Alegre: Bookman.

GAMMELGAARD, B. e LARSON, P.D. (2001). Logistics skills and competencies for supply chain management. Journal of Business Logistics, vol.22 nr.2, pp. 27- 50.

GULATI, R.; GARGIULO, M. (1999). Where Do Interorganizational Networks Come From? American Journal of Sociology. Vol. 104. No. 5.

HAIR, JR. J. F. et al. (2005). Análise Multivariada de Dados. Porto Alegre: Bookman,.

HAYES; J. PISANO; R. (1996). Revisiting Alternative Theoretical Paradigms in Manufacturing Strategy. Production and Op- erations Management, Vol. 9. No. 2, p. 111-127,.

HILL, T. (1995). Manufacturing Strategy: Text and Cases. London: MacMillan Press.,

KUMAR, N.; SCHEER, L.K; STEENKAMP, J.B.E.M. (1995). The Effects of Perceived Interdependence on Dealer Attitudes. Journal of Marketing Research. Vol. 32, No. 3, p. 348-356.

MAGEE, D. (2003). How Carlos Ghosn rescued Nissan. New York: Collins.

MALHOTRA, N. K. (2004). Pesquisa de Marketing: uma orientação aplicada. Porto Alegre: Bookman.

MENTZER, J.T. (2001). Defining supply chain management. Journal of Business Logistics. Vol. 22 N.2, pp.1-25.

MOHR, J. e NEVIN, J.R. (1990). Communication strategies in marketing channels: a theoretical perspective. Journal of Marketing, vol. 54 nr. 4, pp. 36-51..

MOHR, J. SPEKMAN, R. (1994). Characteristics of partnership success: partnership attributes, communication behavior, and conflict resolution techniques. Strategic Management Journal, vol. 15 nr. 2, pp. 135-152.

MORGAN, R. M.; HUNT, S.D. (1994). The Commitment-Trust Theory of Relationship Marketing. Journal of Marketing. Vol. 58, No. 3, p.20-38.

NEW, C. (1992). World-Class Manufacturing Versus Strategic Trade-Offs. International Journal of Operations \& Production Management, Vol. 12, No. 4, p. 19.

PAIVA, E. L.; CARVALHO J. M.; FENSTERSEIFER, J. E. (2004). Estratégia de produção e de operações conceitos, melhores práticas, visão de futuro. Porto Alegre: Bookman.

PARASURAMAN, A., ZEITHAML, V.A. E BERRY, L. (1988). SERVQUAL: A Multiple-Item Scale for Measuring Consumer Perceptions of Service Quality. Journal of Retailing, Vol. 64, No. 1, p. $12-40$.

PAYNE; D. BALLANTYNE. G. 2001Diagnosing Customer Value: Integrating the Value Process and Relationship Marketing. British Journal of Management. Vol. 12, No. 2, p. 159-182,.

PRAHINSKI, C.; BENTON, W. C. (2004). Supplier Evaluations: Communication Strategies to Improve Supplier Performance. Journal of Operations Management, v. 22, p. 39-62.

SHIN, H., COLLIER, D.A., WILSON, D.D. (2000). Supply management orientation and supplier/buyer performance. Journal of Operations Management, (18), pp. 317-333.

SLACK, N.; CHAMBERS, S.; JOHNSTON, R. (1999). Administração da Produção e Operações. São Paulo: Thomson.

SWINK, M.; NARASIMHANA, R.; WANGA, C. (2007). Managing beyond the factory walls: Effects of four types of strategic integration on manufacturing plant performance. Journal of Operations Management. Vol. 25, N.1, p. 148-164.

TUTEN, T.L. URBAN, D.J. (2001). An expanded model of business-to-business partnership formation and success. Industrial Marketing Management. Vol. 30, N.1 , pp. 149-164. 
VERMA, R.; THOMPSON, G. M. (1999). Managing service operations based on customer preferences. International Journal of Operations \& Production Management, v. 19, n. 9, p. 891-905,.

WHEELWRIGHT, S. C. (1984). Manufacturing strategy: defining the missing link. Strategic Management Journal, Vol. 5, p. 77-91.
WINNER, A.; SZÁNTÓ, R.; KISS, N. (2005). Business Relationship Management as a Tool of Performance Management - the cases of successful Hungarian companies. EurOMA International Conference on Operations and Global Competitiveness. Budapest, Hungary. 


\section{APPENDIX 1 - QUESTIONS}

\section{Scale (1=Completely Agree, 5=Completely Disagree)}

It has been absolutely critical for the relationship continuity with your main International Maritime Transporter:

01. Service price (Freight)

02. Scale frequency

03. Transit time

04. Direct shipments (without overflow in other ports)

05. Traceability

06. Right shipment documentation

07. Quick availability of shipment documentation

08. Skilled and capable team

09. Correct payment document

10. Capability related to expected time delivery

11. Availability of space and equipment

12. Safety load (delivery without damage or losses)

13. Easy contact with supplier

14. Ability to adapt the service to my needs

15. Company's market reputation (image)

16. Agile requests response

17. The importer influence

Indicate your agreement level with the sentences below regarding the current operations with your International Maritime Transport suppliers

18. We carry through the act of contract of the transporters through an intermediary (Broker)

19. We use formal election of suppliers methods, with clearly defined criteria

20. We prioritize long-term relationships

21. We invest in suppliers (for qualification)

22. There is effective commitment with suppliers

23. There is a expectation of long term relationship with these suppliers

24. Longevity expectation is shown in some way (in case there is no expectation do not mark an option)

25. The supplier is cooperative in problems solving

26. The supplier shows promptness in needed changes

27. Communication flows clearly

28. Objectives with the communication are achieved

29. Existing relationship influences the supplier choice process

30. We compare other suppliers to our current suppliers

31. The results of this comparison are used to bargain with current suppliers 


\section{AUTHOR'S BIOGRAPHY}

Ely L. Paiva - Doctor in Business Administration by Universidade Federal do Rio Grande do Sul. Full Professor at Unisinos.

Patrícia Phonlor - Master of Science by Unisinos and Bachelor in Administration by FURG.

Lecturer at Faculdade de Integração do Ensino Superior do Cone Sul (FISUL).

Lívia C. D'Avila - Master's Degree Candidate at UNISINOS and Bachelor in Administration by FURG. Lecturer at Faculdades Anhanguera Rio Grande. 